\title{
2022 European Thyroid Association Guideline for the management of pediatric Graves' disease
}

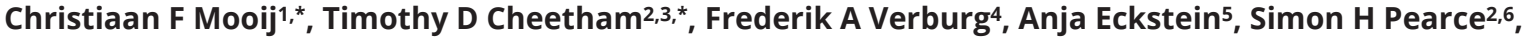 \\ Juliane Léger7 and A S Paul van Trotsenburg1
}

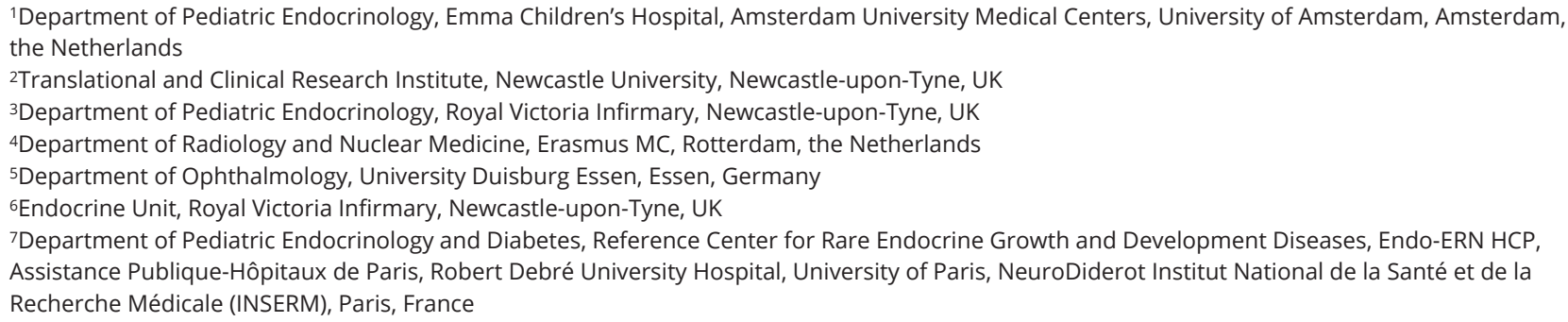

Correspondence should be addressed to C F Mooij or A S P van Trotsenburg: c.mooij@amsterdamumc.nl or a.s.vantrotsenburg@amsterdamumc.nl *(C F Mooij and T D Cheetham contributed equally to this work)

\begin{abstract}
Hyperthyroidism caused by Graves' disease (GD) is a relatively rare disease in children. Treatment options are the same as in adults - antithyroid drugs (ATD), radioactive iodine (RAI) or thyroid surgery, but the risks and benefits of each modality are different. The European Thyroid Association guideline provides new recommendations for the management of pediatric GD with and without orbitopathy. Clinicians should be alert that GD may present with behavioral changes or declining academic performance in children. Measurement of serum TSH receptor antibodies is recommended for all pediatric patients with hyperthyroidism. Management recommendations include the first-line use of a prolonged course of methimazole/carbimazole ATD treatment (3 years or more), a preference for dose titration instead of block and replace ATD, and to avoid
\end{abstract}

\author{
Key Words \\ - Graves' disease \\ - pediatric \\ - childhood \\ - antithyroid drugs \\ - radioactive iodine \\ - total thyroidectomy \\ - management \\ - clinical practice guideline
}

\section{Introduction}

\section{Purpose and scope of guideline}

Hyperthyroidism caused by Graves' disease (GD) is a relatively rare disease in children. Although treatment options are the same as in adults - antithyroid drugs (ATD), radioactive iodine (RAI) and thyroid surgery the benefits and risks of each modality are different in the young. The European Thyroid Association (ETA) guideline addresses the etiology, diagnosis and prognosis of pediatric GD patients with and without orbitopathy and includes evidence-based treatment recommendations. Fetal and neonatal thyroid dysfunction related to maternal GD during pregnancy is not discussed in this guideline.
This work is licensed under a Creative Commons Attribution-NonCommercial-NoDerivatives 4.0 deaternational License.ifica.com at 04/26/2023 01:25:40PM 


\section{Methodology}

A taskforce of European clinician scientists led by a chairman (ASPvT) was established. For three important clinical/treatment topics in pediatric GD, a systematic literature search and evaluation were performed: remission rate and adverse effects associated with ATD treatment; efficacy and safety of RAI; efficacy and safety of thyroidectomy. For additional questions, targeted literature searches were performed. The Grading of Recommendations, Assessment, Development and Evaluation (GRADE) system was used for rating the strength of the recommendations and the quality of the underlying evidence (1). We used the following coding system: ' 1 ', strong recommendation and ' 2 ', weak recommendation or suggestion. The quality of the evidence is rated as level

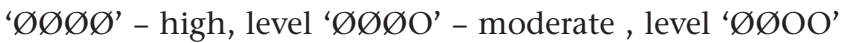
- low, or level 'ØOOO' - very low. The drafted guideline version was discussed within the task force until consensus was reached. The recommendations are listed in Table 1.

\section{Hyperthyroidism}

\section{What is hyperthyroidism?}

Hyperthyroidism is a pathological state characterized by increased synthesis and secretion of thyroid hormones (thyroxine (T4) and triiodothyronine (T3)) by the thyroid gland (2). Thyrotoxicosis refers to the clinical picture of thyroid hormone excess. In childhood, most cases of hyperthyroidism are caused by underlying thyroid disease with high serum free T4 (FT4) or free T3 (FT3) concentrations and a fully suppressed thyrotropin (TSH; <0.1 mIU/L) $(3,4)$. This is known as overt primary hyperthyroidism. Subclinical hyperthyroidism - a milder form - is defined as a low or suppressed TSH $(<0.4 \mathrm{mIU} / \mathrm{L})$, but serum free T4 (FT4) and free T3 (FT3) within the reference interval.

In children, hyperthyroidism is mostly caused by GD and is usually biochemically overt and clinically severe (4). The characteristics of GD and other possible causes of hyperthyroidism and thyrotoxicosis in children are shown in Table 2. Signs and symptoms of hyperthyroidism in children are similar to those in adults. Childhood hyperthyroidism may also cause accelerated growth and bone maturation and deterioration in academic performance (4). In healthy children, thyroid size at physical and ultrasound examination increases with age (5), but in GD, the thyroid is frequently symmetrically enlarged. Increased thyroidal blood flow may result in a thrill or bruit. Manifestations of thyroid eye disease include proptosis and lid retraction and are as common in children as in adults, but inflammatory features are less severe $(6,7)$. In many pediatric GD patients, there is a diagnostic delay due to suspected behavioral, gastrointestinal, respiratory or cardiac disease.

\section{How to diagnose hyperthyroidism?}

In all pediatric patients with suspected hyperthyroidism, serum FT4, FT3 and TSH should be measured. Since GD is the most frequent cause of hyperthyroidism, anti-TSH receptor and anti-thyroperoxidase antibodies (TSHRAb - also known as thyroid-binding inhibitory immunoglobulin or TBII - and anti-TPO, respectively) should also be measured (4). An elevated FT3 level is a more sensitive marker of overt hyperthyroidism than FT4. This biochemical evaluation will confirm or refute the diagnosis of pediatric GD in most cases (Table 2). If the clinical picture is suggestive of GD but thyroid antibodies are absent, they should be repeated a few weeks later. If there are still no signs of thyroid autoimmunity, thyroid ultrasonography, scintigraphy - preferably with Tc-99m-pertechnetate - and additional laboratory investigations can be considered (Table 2). To avoid radiation exposure, thyroid ultrasonography with Doppler blood flow assessment is preferred over scintigraphy (8), but scintigraphy is better for diagnosing a 'hot' autonomous nodule and excluding low iodine uptake thyrotoxicosis.

\section{Graves' disease}

\section{What is Graves' disease?}

GD is an autoimmune disorder characterized by the presence of TSHRAb resulting in an overactive thyroid gland (Graves' hyperthyroidism), ocular abnormalities (Graves' orbitopathy, GO) and - very rarely - localized dermopathy (pretibial myxoedema, PTM) (9). TSHRAb act as agonist, induce excessive thyroid hormone secretion and uncouple the thyroid from pituitary control (10). They also stimulate thyroid gland growth via similar, but not identical, signal transduction. In the orbit, TSHRAb stimulation of fibroblasts expressing TSHR induces hyaluronan production, potentiated by cross-talk between TSHR and insulin-like growth factor 1 receptors. This is accompanied by retro-orbital inflammation, extraocular muscle fiber disruption and tissue edema (11). Finally,
This work is licensed under a Creative Commons Attribution-NonCommercial-NoDerivatives 4.0 International License ifica.com at 04/26/2023 01:25:40PM 
Table 1 European Thyroid Association 2022 recommendations for the management of pediatric Graves' disease.

Medical treatment of hyperthyroidism caused by Graves' disease (GD)

- Patients with GD require prompt treatment $(1, \varnothing \varnothing \varnothing \varnothing)$.

- Either carbimazole (CBZ) or its active metabolite methimazole (MMI) should be used in young people with GD. Propylthiouracil should not be used $(1, \varnothing \varnothing \varnothing \varnothing)$.

- The initial antithyroid drug (ATD) dose is between 0.15 and $0.5 \mathrm{mg} / \mathrm{kg}$ of MMI or between 0.25 and $0.75 \mathrm{mg} / \mathrm{kg}$ of CBZ daily. Both drugs are given once daily $(1, \varnothing \varnothing \varnothing 0)$.

- Dose titration (DT) approach: with a DT approach, a starting dose of 0.15-0.3 mg/kg MMl or 0.25-0.5 mg/kg CBZ will normalize thyroid hormone concentrations in most patients within the first 4-6 weeks. The dose is then reduced by $25-50 \%$ according to prevailing thyroid function tests. Larger doses of ATD up to $0.5 \mathrm{mg} / \mathrm{kg} \mathrm{MMI} \mathrm{or} 0.75 \mathrm{mg} / \mathrm{kg}$ CBZ can be administered in more severe, symptomatic cases $(1, \varnothing \varnothing \varnothing 0)$.

- The treatment regimen may not require adjustment if FT4 or FT3 is relatively high but TSH is normal $(1, \varnothing 000)$.

- Education about GD and especially its treatment is essential to optimize compliance, with attention to the developmental age $(1, \varnothing \varnothing 00)$.

- Block and replace (BR) approach: a dose of 0.3-0.5 mg/kg MMI or 0.5-0.75 mg/kg CBZ will prevent endogenous thyroid hormone production in most patients. Levothyroxine can be introduced in an age and weight-appropriate replacement dose as the FT3 falls into the reference range. Higher doses of ATD can be used (for example $1.0 \mathrm{mg} / \mathrm{kg} \mathrm{MMI} \mathrm{or} 1.3 \mathrm{mg} / \mathrm{kg}$ CBZ) if thyroid hormone concentrations, especially FT3, do not fall as expected $(1, \varnothing \varnothing \varnothing 0)$.

- DT is the preferred means of ATD treatment in most cases $(1, \varnothing \varnothing \varnothing \varnothing)$.

- Beta-adrenergic blockade is recommended in patients presenting with marked signs of thyroid hormone excess. This can be stopped once the patient is biochemically euthyroid $(1, \varnothing \varnothing \varnothing 0)$.

- Patients with untreated GD can be severely unwell with marked signs of thyroid hormone excess. Such patients should be managed on a high dependency or intensive care unit $(1, \varnothing \varnothing \varnothing 0)$.

- Patients managed with DT or BR should be seen approximately every 4 weeks for the first 3 months, moving to 2 and then 3 monthly assessments thereafter depending on the clinical course $(1, \varnothing \varnothing \varnothing 0)$.

- A white cell count including neutrophil count and liver function tests should be checked at baseline because both can be affected by the underlying disease process and ATD therapy $(1, \varnothing \varnothing \varnothing 0)$.

- Thyroid hormone concentrations (FT4 and FT3) should normalize in most patients in the first 6 weeks with a noticeable improvement in the first 4 weeks. TSH can remain suppressed for several months $(1, \varnothing \varnothing \varnothing 0)$.

- Families should be warned about susceptibility to excessive weight gain while on ATD therapy $(1, \varnothing \varnothing \varnothing 0)$.

- Minor ATD side effects occur in 10 to $20 \%$ of patients and are usually transient. Serious side-effects that warrant stopping ATD

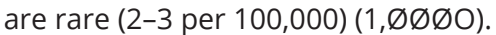

- Patients and families should be counseled about ATD side effects and the criteria for stopping the drug and seeking health professional guidance $(1, \varnothing \varnothing \varnothing \varnothing)$.

- Alternative treatment with surgery or RAI should be discussed in patients who are thyrotoxic despite large doses of CBZ $(\geq 1.3 \mathrm{mg} / \mathrm{kg} /$ day) or MMI ( $\geq 1 \mathrm{mg} / \mathrm{kg} /$ day) $(1, \varnothing \varnothing \varnothing 0)$.

- Definitive treatment (total thyroidectomy or RAl) should be considered in patients who develop severe neutropenia, significant liver dysfunction or troublesome side-effects that fail to resolve. Definitive treatment may also be appropriate when patients cannot accurately report potential ATD side effects, refractory compliance issues or when prolonged ATD therapy has not resulted in remission $(1, \varnothing \varnothing \varnothing \varnothing)$.

- TSH receptor antibodies (TSHRAb) can be used to predict the likelihood of remission. If TSHRAb are elevated then remission is

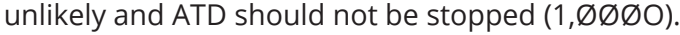

- ATD is normally administered for at least 3 years and only stopped when TSHRAb levels have been low for several months. Longer courses of ATD ( $\geq 5$ years) should be considered if the likelihood of remission is low on the basis of disease characteristics at presentation $(1, \varnothing \varnothing \varnothing 0)$.

- The overall remission rate after ATD treatment in pediatric GD patients is between 20 and $30 \%$ after 2 years of ATD treatment

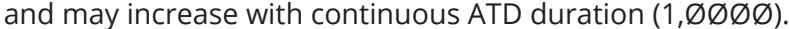

- The signs of thyroid hormone excess should be discussed when ATD is stopped and a pathway for thyroid function testing agreed $(1, \varnothing \varnothing \varnothing 0)$.

- Patients who relapse following a course of ATD have the option of returning to ATD or choosing definitive treatment. The decision may be influenced by factors such as age or stage of education $(1, \varnothing \varnothing \varnothing 0)$.

- There is no established role for immune modulation with new agents such as biologics in the young person with GD (1, $\varnothing \varnothing \varnothing 0)$.

Definitive treatment in pediatric GD - radioiodine (RAI)

- The objective of RAI (I-131) treatment is complete thyroid ablation. This is to prevent relapse and future development of thyroid cancer (1,ØØ००).

- RAl should be avoided in patients younger than 5 years and only used in the age group 5-10 years when surgery is not a realistic option. There is no contraindication to RAl use in patients older than 10 years/post-pubertal children $(1, \varnothing \varnothing 00)$.

- RAl activity should ideally be personalized using an activity of $15 \mathrm{MBq}(0.4 \mathrm{miCi})$ per gram thyroid tissue when dosimetry is difficult to organize or should aim at delivering at least $300 \mathrm{~Gy}$ to the thyroid gland when dosimetry is used. For the purpose of I-131 dose calculation, thyroid weight is best estimated by ultrasound $(2, \varnothing \varnothing \varnothing 0)$.

- Before RAI, ATD should be stopped for 3-7 days (1,ØØØO).

- RAl therapy should be avoided in the presence of active Graves' orbitopathy (GO). In the case of inactive GO, a course of steroids should be given concurrently in order to prevent relapse/exacerbation $(1, \varnothing \varnothing \varnothing \varnothing)$.

(Continued)

https://etj.bioscientifica.com

https://doi.org/10.1530/ETJ-21-0073 (c) 2022 European Thyroid Association Published by Bioscientifica Ltd.

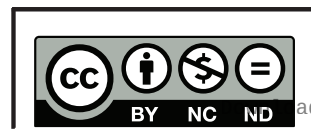

This work is licensed under a Creative Commons Attribution-NonCommercial-NoDerivatives 4.0 International License.ifica. com at 04/26/2023 01:25:40PM 
Table 1 Continued.

Definitive treatment in pediatric Graves' disease - thyroidectomy

- Pediatric patients undergoing thyroidectomy should be operated on by a high-volume thyroid surgeon $(1, \varnothing \varnothing \varnothing \varnothing)$.

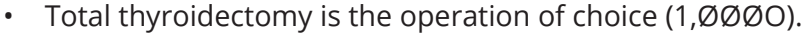

- The pediatric GD patient should be biochemically euthyroid prior to surgery. Pre-operative treatment with ATDs and, if necessary, iodine, a beta-blocker and glucocorticoid may be needed $(1, \varnothing \varnothing \varnothing \varnothing)$.

- Pre-operative treatment with vitamin $\mathrm{D}$ reduces the risk of post-operative transient hypocalcemia in those who are not vitamin $\mathrm{D}$ replete $(2, \varnothing \varnothing 00)$.

- Levothyroxine treatment should be started soon after thyroidectomy (1,ØØ००).

Management of pediatric Graves' orbitopathy

- Children with eye symptoms should be seen by an orbital specialist, preferably in combined (ophthalmologist/physician) thyroid eye clinics $(1, \varnothing \varnothing \varnothing 0)$.

- Mild GO symptoms without inflammatory features can be followed expectantly or, if indicated, with selenium supplementation $(2, \varnothing \varnothing 00)$.

- Rare cases of moderate to severe active GO cases can be treated with anti-inflammatory drugs (e.g. i.v. corticosteroids) $(1, \varnothing \varnothing 00)$.

- Chronic inactive stable GO, which may reduce quality of life, can be treated surgically as in adults; however, except for decompression surgery this should be postponed until the facial skull has fully grown $(1, \varnothing \varnothing 00)$.

Management of an increased thyroid cancer risk

- Young patients with GD may, like adults, have a slightly higher risk of developing differentiated thyroid cancer (2,ØØంO).

- Children and adolescents with GD who have a palpable thyroid nodule should be managed by a pediatric endocrinologist in collaboration with a pertinent multi-disciplinary team (2,Ø0००).

- Young patients with a thyroid nodule/nodules should either be evaluated by thyroid ultrasound, and proceed to cytological evaluation if indicated from the sonographic findings, or undergo total thyroidectomy $(2, \varnothing \varnothing ం ०)$.

Prognosis

- Young people diagnosed with GD, diagnosed and treated in childhood, may have a lower quality of life than healthy peers. This should be kept in mind and, where necessary, appropriate steps are taken to address this $(1, \varnothing \varnothing \bigcirc 0)$.

TSHR stimulation induces fibroblasts to differentiate into adipocytes, resulting in tissue expansion in the orbit (12).

The etiopathogenesis of GD is not fully understood. Genetically determined immunological susceptibility appears to interact with environmental insults (e.g. cigarette use, infection, stress and gut microbiota). Genetic susceptibility is linked to the HLA locus and other immune-related genes (e.g. CTLA4, IL-2RA and PTPN22) and thyroid-specific genes (e.g. TG and TSHR) (13, 14, 15). HCP5 polymorphisms have been associated with a younger age at GD onset $(16,17)$. GD is associated with the occurrence of other autoimmune disorders such as type I diabetes mellitus, celiac disease and vitiligo and is more common in Down syndrome $(4,18)$. In approximately $15 \%$ of cases, there is a first-degree relative with autoimmune thyroid disease. GD can also occur following bone marrow transplantation and HIV therapies (19).

\section{What is the incidence and prevalence of GD in children?}

Childhood GD accounts for 5\% of all GD cases throughout life (20). The overall incidence in children and adolescents is around $4.58 / 100,000$ per year, but before age 15 years, the incidence is lower: 1 to $2.91 / 100,000$ per year. GD is 3.4 times more common in girls than boys (21). Before age 5 years, the prevalence is about ten times lower, with a girls-to-boys ratio of 1.4. This ratio increases markedly with age, particularly in the second decade of life $(21,22)$. GD incidence varies between countries and may be rising $(23,24)$.

\section{Treatment of hyperthyroidism caused by Graves' disease}

\section{General considerations}

Because of deleterious effects of excess thyroid hormone on multiple organ systems, children with GD require prompt treatment. Occasional, evolving 'mild' cases, including subclinical hyperthyroidism with minimal clinical and biochemical disturbance, may benefit from a period of surveillance to clarify the need for treatment.

In general, initial treatment is medical. When this fails or is not possible, a definitive treatment should be considered. The proposed approach to treatment and follow-up is a general one and - depending on specific patient characteristics - can be individualized.
This work is licensed under a Creative Commons Attribution-NonCommercial-NoDerivatives 4.0 International License.ifica.com at 04/26/2023 01:25:40PM 

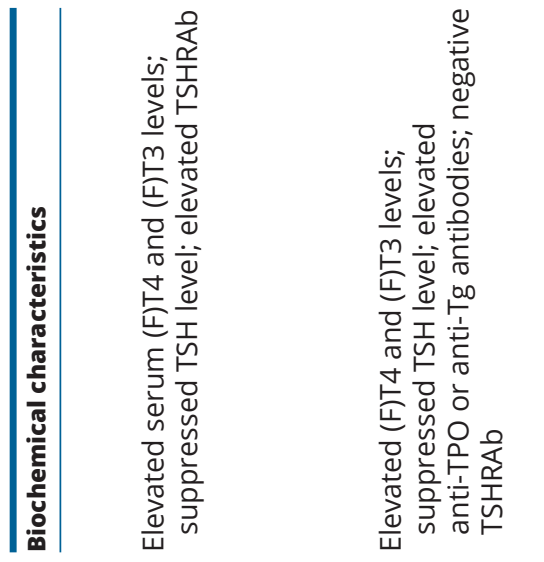

घ)
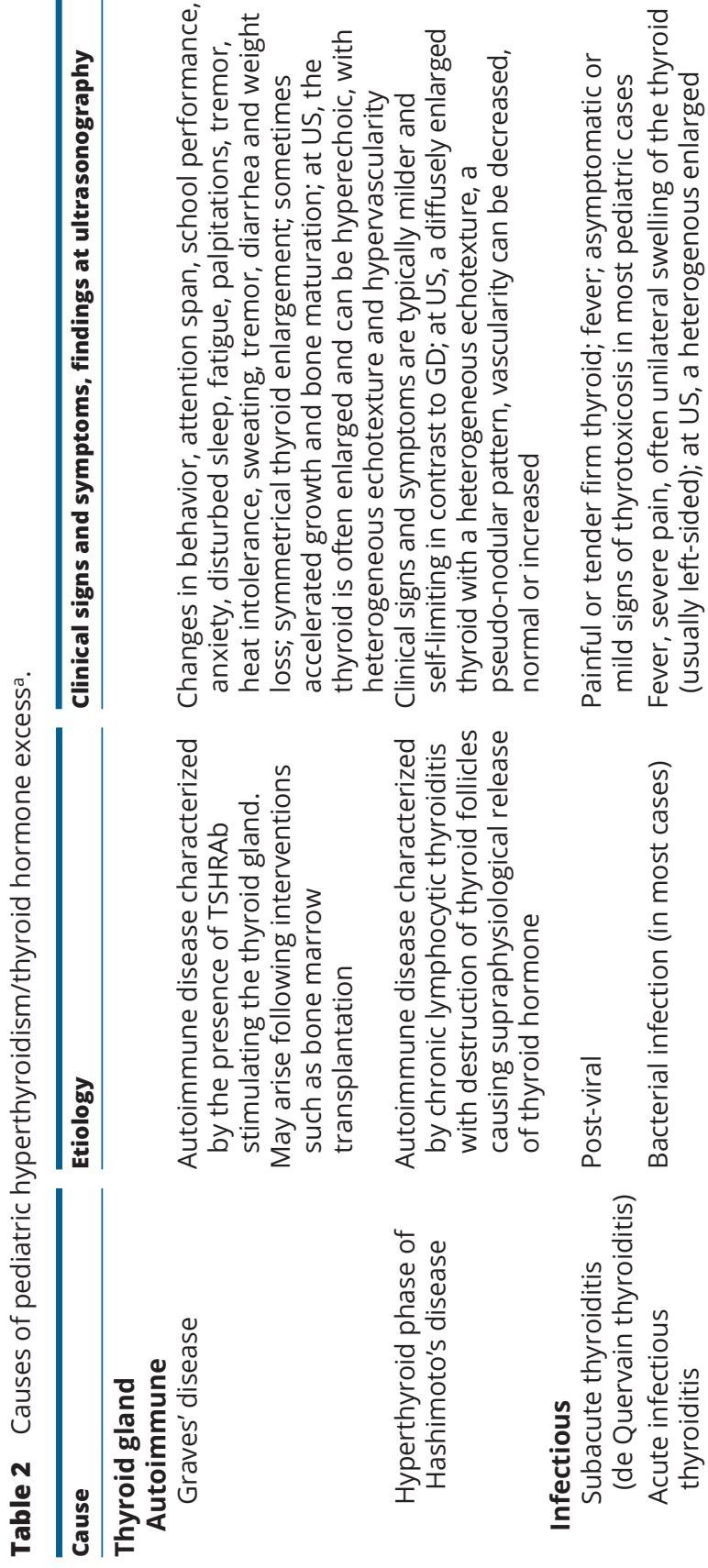
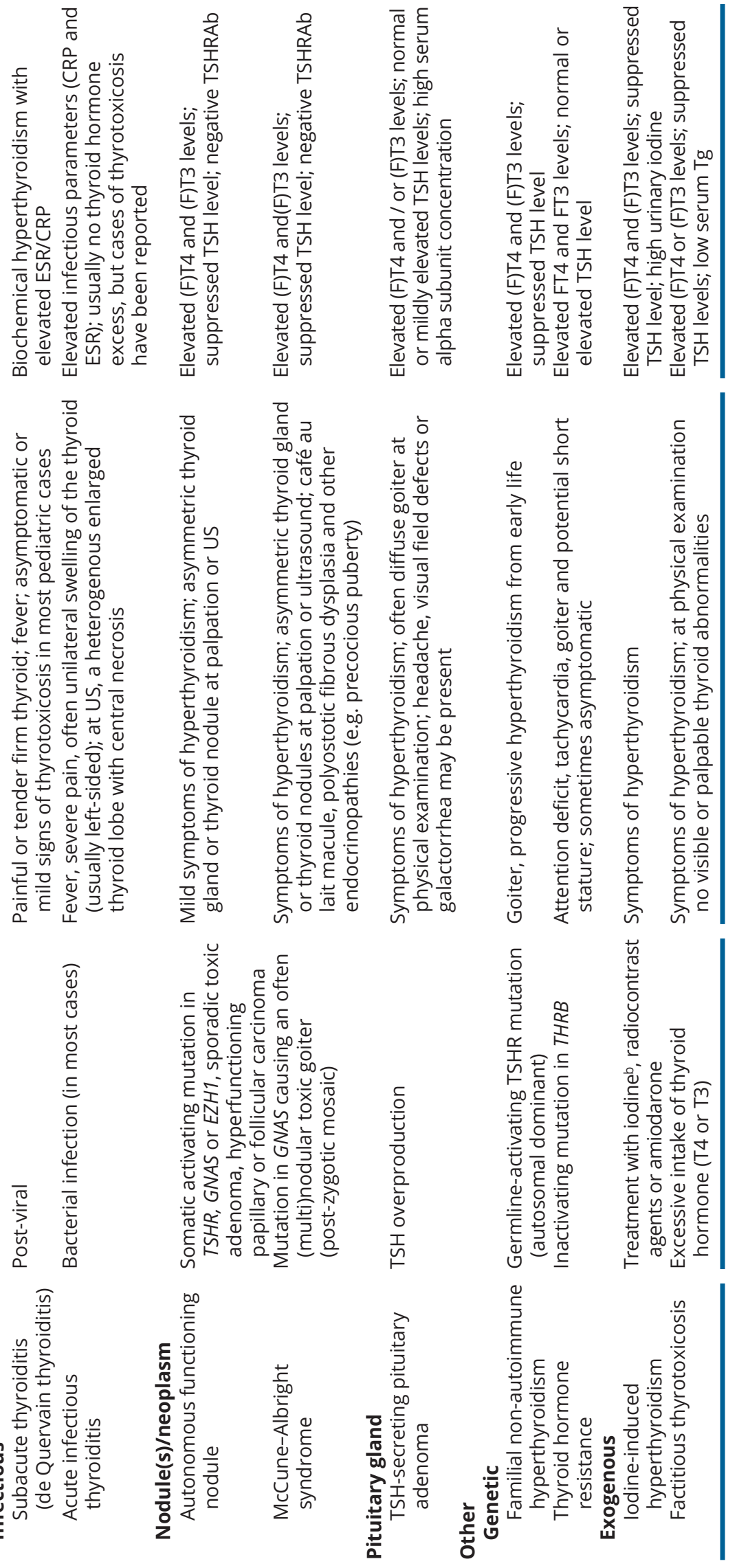

号

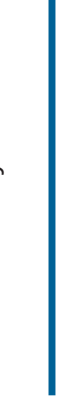

() 2022 European Thyroid Association Published by Bioscientifica Ltd. 


\section{Medical treatment - antithyroid drugs}

\author{
Which antithyroid drug(s) (ATD) can be used in \\ children?
}

The thionamide carbimazole (CBZ) or its active metabolite methimazole (MMI; also known as thiamazole) can be used to treat hyperthyroidism. Propylthiouracil (PTU) should not be used because of the risk of hepatic failure (25). Thionamides act as a preferential substrate for thyroid peroxidase (TPO), thereby preventing tyrosine iodination in the thyroglobulin molecule and blocking thyroid hormone synthesis. Although a direct immunomodulatory action has been proposed (26), rendering the patient euthyroid has a beneficial effect on autoimmunity in itself (27).

\section{What is the (optimal) ATD starting dose?}

ATD can be titrated against thyroid function tests (dose titration, DT) or administered in a larger dose to prevent endogenous thyroid hormone production, with levothyroxine (LT4) added later in a replacement dose (block and replace, BR). The ATD starting dose will depend on weight, signs, symptoms and biochemical severity.

MMZ of $0.6 \mathrm{mg}$ is approximately equivalent to $1.0 \mathrm{mg}$ CBZ. MMZ of $0.5 \mathrm{mg} / \mathrm{kg}$ or CBZ of $0.75 \mathrm{mg} / \mathrm{kg}$ will block thyroid hormone production in the majority of patients. A lower starting dose of $0.15 \mathrm{mg} / \mathrm{kg}$ of MMZ or $0.25 \mathrm{mg} / \mathrm{kg}$ CBZ can be used in mild to moderate disease (e.g. FT4 $\leq 35 \mathrm{pmol} / \mathrm{L}$ or FT3 $\leq 12 \mathrm{pmol} / \mathrm{L}$ ). MMZ/CBZ can be administered once daily $(28,29,30)$.

\section{Dose titration}

A starting dose of $0.15-0.3 \mathrm{mg} / \mathrm{kg} \mathrm{MMZ}$ or $0.25-0.5 \mathrm{mg} / \mathrm{kg}$ CBZ will normalize thyroid hormone concentrations in most patients with the dose then reduced to prevent hypothyroidism. Larger ATD doses $(0.5 \mathrm{mg} / \mathrm{kg}$ MMI or 0.75 $\mathrm{mg} / \mathrm{kg}$ CBZ) can be administered in more severe cases where a more rapid reduction in thyroid hormone concentrations is desirable. The ATD dose required to maintain euthyroidism will depend on disease severity. TSHRAb concentrations fall during ATD therapy and so the ATD dose can sometimes be reduced to 2.5-5 mg MMZ or CBZ daily in the longer term.

\section{Block and replace}

A dose of $0.3-0.5 \mathrm{mg} / \mathrm{kg}$ MMZ or 0.5-0.75 mg/ $\mathrm{kg}$ CBZ will usually result in hypothyroidism. LT4 in an age and weightappropriate replacement dose should be started when thyroid hormone levels normalize/before hypothyroidism supervenes. Higher ATD doses (e.g. $1.0 \mathrm{mg} / \mathrm{kg} \mathrm{MMZ}$ or $1.3 \mathrm{mg} / \mathrm{kg} \mathrm{CBZ}$ ) can be used initially in severe disease or if thyroid hormone concentrations do not fall as expected.

\section{What is the preferred approach, DT or BR?}

A recent RCT showed no difference in biochemical control between DT and BR, but more adverse events in BR (31). Therefore, in most cases, DT is preferred. Earlier studies can be interpreted as demonstrating greater biochemical stability with BR $(32,33,34)$, and there may be occasions when the pediatric endocrinologist discusses the theoretical advantages of BR with families.

\section{What are the indications for beta- adrenergic blockade?}

A beta-blocker (e.g. propranolol or atenolol) should be administered in an age- or weight-appropriate dose when there are signs of moderate to severe thyroid hormone excess (35) but are contraindicated in patients with asthma. The beta-blocker can be stopped once thyroid hormone levels normalize.

\section{Thyroid storm}

Occasionally, patients with GD present with a thyroid crisis or 'storm'. The associated clinical picture includes tachycardia, heart failure, hyperthermia, extreme anxiety, altered mental state and gastrointestinal upset. This may arise in untreated GD or be precipitated by additional factors such as infection, surgery or RAI therapy. In these circumstances, euthyroidism can be reached more rapidly by administering iodine (e.g. potassium iodide solution) and a glucocorticoid, in addition to ATD and a betablocker. ATD and iodine (ATD an hour before iodine to stop the release of preformed thyroid hormone) are used to block thyroid hormone synthesis and secretion, while glucocorticoids inhibit the peripheral conversion of the (inactive) prohormone T4 to metabolically active T3. Betablockers attenuate the peripheral adrenergic actions of the thyroid hormone. Patients in thyroid storm should be managed in a high or intensive care setting. The possibility that iodine administration may complicate RAI treatment or result in hyperthyroidism at a later stage needs to be considered. In general, GD patients should avoid excess nutritional iodine intake because this may aggravate hyperthyroidism.
This work is licensed under a Creative Commons Attribution-NonCommercial-NoDerivatives 4.0 deaternational License ifica.com at 04/26/2023 01:25:40PM 


\section{How should the patient's thyroid status be monitored while on ATD treatment?}

Tables 3 and 4 describe frameworks for managing patients with DT and BR, respectively. Patients can be seen and thyroid status can be assessed every 4 weeks for the first 3 months, moving to 2- to 3-monthly assessments thereafter.

\section{What other tests are required besides thyroid function tests?}

Hyperthyroidism can, like ATD, be associated with a low white cell count and hepatic dysfunction $(36,37)$. A full blood count (FBC) and liver function should therefore be assessed pre-treatment so that subsequent investigations can be placed into context. The timing of FBC/liver function assessments while on ATD is discussed in more detail below.

Table 3 Framework for managing patients with dose titration.

Objective of treatment: maintain thyroid hormone concentrations within the laboratory reference range with a detectable TSH that is below the upper limit of the reference range.

Start of treatment: MMI is commenced in a dose of $0.5 \mathrm{mg} / \mathrm{kg} /$ day $(0.75 \mathrm{mg} / \mathrm{kg} /$ day CBZ) until thyroid hormone levels fall toward or into the local laboratory normal range. A lower starting dose of ATD can be used in the case of mild to moderate hyperthyroidism.

Thereafter:

- As the patient becomes euthyroid or hypothyroid, then the $\mathrm{MMI} / \mathrm{CBZ}$ (ATD) dose can be reduced by approximately $25-50 \%$ (euthyroid) or 50\% (hypothyroid).

- If the patient remains hyperthyroid, then the ATD dose can be increased by approximately $25 \%$ or more if the hyperthyroidism is severe.

- Be guided by thyroid hormone concentrations (not TSH) in the first 4-6 months after diagnosis.

- Be guided by thyroid hormone concentrations as well as TSH concentrations beyond 4-6 months; if TSH concentrations remain persistently suppressed in the presence of a normal FT4, this may reflect elevated FT3; consider increasing the dose of ATD a little.

- Discuss the importance of compliance on a regular basis as well as the importance of stopping ATD therapy in the event of a sore throat or fever with agranulocytosis.

- A raised TSH above the local laboratory normal range despite a minimum daily dose of ATD (e.g. $2.5 \mathrm{mg}$ of MMI or CBZ daily) together with normal TSHRAb suggests that the patient is in remission or has evolving thyroid gland failure and that ATD can potentially be stopped.

ATD, antithyroid drug; CBZ, carbimazole; FT3, free triiodothyronine; FT4, free thyroxine; kg, kilogram; MMI, methimazole; TSH, thyrotropin; TSHRAb, TSH receptor antibodies.
Table 4 Framework for managing patients with block and replace.

Objective of treatment: maintain thyroid hormone

concentrations within the laboratory reference range with a

$\mathrm{TSH}$ that is also within the normal laboratory range (neither

elevated nor suppressed).

Start of treatment: $\mathrm{MMI}$ is commenced in a dose of

$0.5 \mathrm{mg} / \mathrm{kg} /$ day $(0.75 \mathrm{mg} / \mathrm{kg} /$ day CBZ).

Thereafter:

- This ATD dose will block endogenous thyroid hormone release in most patients. If thyroid hormone concentrations remain elevated at 3-4 months into treatment with a suppressed TSH, then discuss compliance and consider increasing the dose of ATD by $25 \%$.

- As thyroid hormones (FT4/FT3) normalize, start LT4 in a relatively low dose (age and weight appropriate). Bear in mind that FT3 will take longer to normalize than FT4.

- If TSH is suppressed, but FT4/FT3 is low or in the bottom part of the normal range in the initial phase of treatment (the first 4 months), then LT4 should still be commenced.

- After initiation of LT4 replacement treatment, dose titrate LT4 guided by biochemistry (FT4) every 4-6 weeks until stable values are achieved.

- If the patient becomes thyrotoxic with a suppressed TSH when the biochemistry (FT4 and FT3) normalized at an earlier stage, then check compliance, make sure iodine intake has not increased substantially and consider increasing the ATD dose. Review TSHRAb titers.

- Discuss the importance of compliance to ATD therapy on a regular basis, revisiting the importance of stopping ATD therapy in the event of a sore throat or fever

ATD, antithyroid drug; CBZ, carbimazole; FT3, free triiodothyronine; FT4, free thyroxine; LT4, levothyroxine; MMI, methimazole; TSH, thyrotropin; TSHRAb, TSH receptor antibodies.

What is the response to ATD, what can the physician and patient expect?

\section{Short term}

Most patients will be biochemically euthyroid within 4-6 weeks, although the timeline will depend on disease severity, ATD dose and compliance. Patients with higher baseline thyroid hormone concentrations may take a longer time to normalize. Moreover, ATDs build up in the thyroid over a few weeks, and improvement in symptoms may not be immediate.

\section{Longer term}

Although most patients have a BMI SD score within normal limits at diagnosis, excessive weight gain can occur after euthyroidism is restored (38).

\section{What are the side effects of ATD treatment?}

Around $15 \%$ of pediatric GD patients on ATD (mainly $\mathrm{MMI} / \mathrm{CBZ}$ ) develop at least one side effect/adverse event

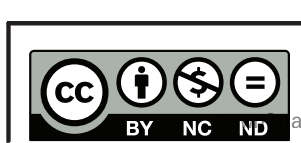

This work is licensed under a Creative Commons Attribution-NonCommercial-NoDerivatives 4.0 International License.ifica.com at 04/26/2023 01:25:40PM 
(AE) (Supplementary Table 1, see section on supplementary materials given at the end of this article). The most frequent minor side effect is a cutaneous reaction (pruritic rash and urticaria; $\approx 10 \%$ ). Hepatitis/liver dysfunction with CBZ/ MMI is cholestatic and resolves when ATD is stopped (39), in contrast to the hepatocellular damage seen with PTU. Major side effects like agranulocytosis are reported very rarely in pediatric GD patients (40). The majority of AEs occur in the first 3 months with a higher rate in younger children $(41,42)$. Severe AEs may be dose-dependent (27).

\section{Managing ATD side effects}

Patients and families should be counseled about ATD side effects. In case of agranulocytosis/severe neutropenia, the patient should stop ATD and undergo determination of neutrophil count in the event of signs or symptoms of infection like fever or a sore throat. ATD-associated neutropenia typically develops in the first month of treatment (median 30 days), although there are rare cases of patients developing neutropenia after many years on treatment (43). Management is complicated by the fact that a low neutrophil count can reflect the disease process or recent infection. If the neutrophil count is below 0.5 $\left(\times 10^{9} / \mathrm{L}\right)$, then the ATD should be stopped and alternative treatment should be initiated. A neutrophil count between 0.5 and 1.5 can be monitored closely with once or twice weekly measurements. Some ATD side effects such as rash can be managed symptomatically knowing that they usually settle spontaneously, although, in the presence of mucosal blistering, which may herald Stevens-Johnson syndrome, ATD should be stopped immediately (42, 44). An increased transaminase level (>three times the upper limit of normal) during treatment warrants ATD cessation and so liver function tests should be performed in the event of pertinent signs of liver dysfunction (4). $\mathrm{MMI} / \mathrm{CBZ}$ should not be recommenced in an individual who has experienced a serious complication linked to earlier MMI/CBZ administration.

\section{Management of patients who do not become euthyroid on a substantial dose of ATD}

Occasionally, patients remain thyrotoxic on doses of $\mathrm{MMI} / \mathrm{CBZ}$ in excess of $0.6 \mathrm{mg} / \mathrm{kg} / \mathrm{day}$ or $1 \mathrm{mg} / \mathrm{kg} / \mathrm{day}$, respectively. Compliance and exacerbation by the use of iodine-containing supplements should be discussed. The risk of adverse events may increase with higher doses, and while the ATD dose can be increased to $1.0 \mathrm{mg} / \mathrm{kg} /$ day
(MMI) or $1.3 \mathrm{mg} / \mathrm{kg} /$ day (CBZ), it is appropriate to discuss the role of surgery or RAI with families as well (45).

\section{What are the criteria for definitive treatment while under treatment?}

Total thyroidectomy or RAI is the treatment options for patients who develop ATD side effects such as severe neutropenia or significant liver dysfunction. These treatments may also be selected if the patient or parents are unable to report ATD side effects (e.g. learning disability), if they have relapsed and do not want further ATD, or where there is long-standing poor compliance.

\section{What is the role of TSHRAb measurement during ATD therapy?}

When considering whether ATD should be stopped, TSHRAb can be used to predict the likelihood of relapse. If the TSHRAb titer is elevated, then remission is unlikely (46).

\section{What are the remission and relapse rates after ATD treatment?}

The overall remission rate after 2 years of ATD treatment in pediatric GD patients is $20-30 \%(40,47)$. The remission rate increases with longer treatment duration. Remission rates of $24.1,31.0$ and $43.7 \%$ are reported after treatment durations of $1.5-2.5,2.5-5$ and 5-6 years, respectively $(40,48)$. One study with a treatment duration of 9 years reported a remission rate of $75 \%$ (Fig. 1) (49).

\section{When should ATD be stopped?}

Treatment duration should be at least 3 years and potentially 5 years or longer if the likelihood of remission is low based on patient characteristics at presentation (Table 5). ATD can be continued for many years although the likelihood of long-term remission if ATD were stopped should be discussed regularly with families. Those patients who are likely to remit when ATD are stopped will usually be on a low dose of ATD and have no detectable TSHRAbs. TSHRAb decline by a median of $90 \%$ after 3 years of ATD treatment and ATD should not be stopped if TSHRAb are raised $(46,50)$. Patients who relapse when ATD is stopped usually do so within 12 months (47), and so treatment cessation should not usually be in the period leading up to key educational milestones such as examinations. 


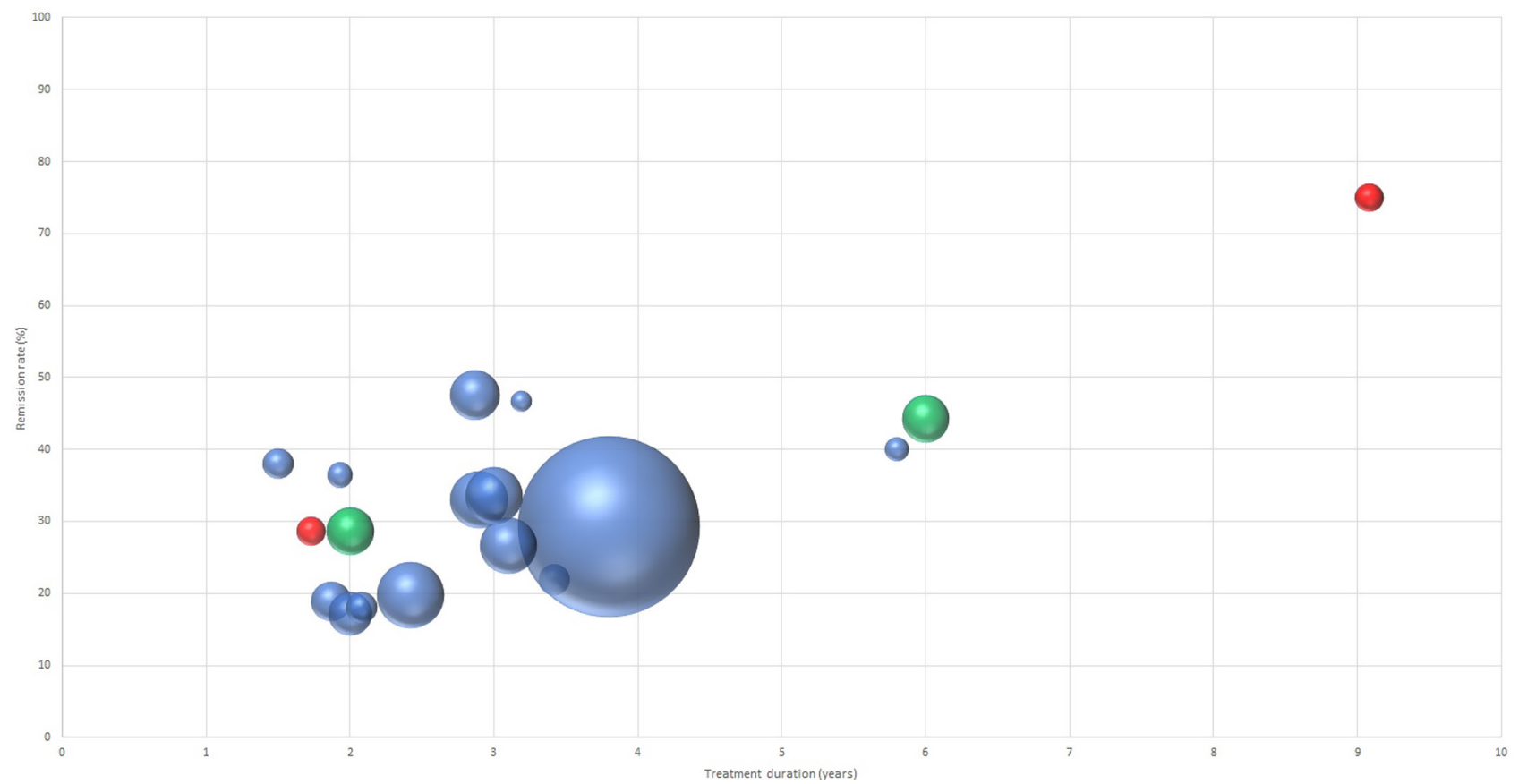

\section{Figure 1}

Remission rates in relation to duration of medical treatment (methimazole or carbimazole) in patients with pediatric Graves' disease. Remission rates reported in the systematic review by van Lieshout et al. (40) (Table 2) evaluating studies on the efficacy of treatment with methimazole or carbimazole in relation to the treatment duration in pediatric Graves' disease. Size of the bubble reflects the size of the patient population. Prospective studies comparing standard and long-term treatment durations are displayed twice in this figure (Azizi et al. (49) displayed in red, and Léger et al. and Kaguelidou et al. $(47,48)$ displayed in green).

\section{How should patients be followed up after stopping ATD?}

Patients and families should be familiar with the manifestations of thyrotoxicosis, and patients should have thyroid function checked if relapse is suspected, or every 3-4 months after stopping ATD in the first year, every 6 months in the second year and annually thereafter; not only because of the risk of relapse but also of autoimmune hypothyroidism (see prognosis) (51). Patients can be referred back to their family doctor after 12-24 months, with advice to monitor thyroid function for at least

Table 5 Factors associated with improved likelihood of remission following antithyroid drug treatment.

Older age $(47,99)$

Female sexa (100)

Ethnicity (Caucasian) (47)

Small goiter size (101)

Mild biochemical derangement at diagnosis (48)

Lower TSHRAb titer (47)

History of other autoimmune conditions (48)

Duration of ATD treatment $(48,102)$

aln adult studies only.

ATD, antithyroid drug; TSHRAb, TSH receptor antibodies. Published by Bioscientifica Ltd.
10 years or in case of symptoms or signs of hyperthyroidism. The possibility of TSHRAb crossing the placenta and affecting the health of the fetus years later should be discussed with females pre-discharge and reinforced by pertinent text in associated correspondence. Evaluation of thyroid function pre-conception and TSHRAb levels when pregnant (especially after definitive treatment for GD) is needed.

\section{What to do when a patient experiences a relapse after ATD treatment?}

Some patients who relapse may still remit in the long term depending on associated features (Table 5). This should be taken into consideration when considering the role of further ATD.

Is there a role for new treatment modalities like immune modulation in the treatment of pediatric GD?

There are case reports and series describing the clinical course of adult patients receiving biologics like rituximab or TSHR-blocking antibodies (K1-70) as a treatment for GD

is work is licensed under a Creative Commons Attribution-NonCommercial-NoDerivatives 4.0 International License.ifica.com at 04/26/2023 01:25:40PM 
$(52,53,54,55,56,57,58)$. There is insufficient evidence to suggest that these agents are of benefit in pediatric GD.

\section{Definitive treatment - radioiodine or surgery}

Indications for definitive treatment include relapse after ATD treatment, serious or persistent side effects of ATD, poor compliance or obstructive symptoms from a large goiter $(4,59,60)$.

\section{Radioiodine treatment}

Like iodine, RAI is taken up and metabolized by the thyrocyte and stored within the thyroid follicle as thyroid hormone. Isotope decay with the emission of betaradiation damages thyrocyte DNA resulting in apoptosis and tissue necrosis. Sufficient RAI activity will destroy the thyroid gland resulting in hypothyroidism.

When RAI is chosen as definitive treatment, we advise aiming for thyroid ablation in order to minimize the risk of relapse and (future) malignant transformation of persistent, viable but radiation-damaged cells.

When administering RAI, there are various methods for calculating appropriate activity, including a fixed approach with activities ranging from 200 to $800 \mathrm{MBq}$ (61), limited personalization in the form of (preferably) $15 \mathrm{MBq}$ I-131 per gram thyroid tissue (thyroid volume/weight estimated by ultrasound) (62) or dosimetry aiming at delivering at least $300 \mathrm{~Gy}$ to the thyroid gland for functional ablation (61). No method is demonstrably superior to others, although higher activities/doses are usually associated with higher rates of complete functional ablation. No adult or pediatric studies demonstrate a $100 \%$ success rate. For the greatest chance of success, while at the same time minimizing excessive radiation exposure, we recommend performing thyroid dosimetry if available.

RAI can theoretically be used in any patient with GD, but contraindications are pregnancy (and becoming pregnant within 6 months after RAI), breast-feeding, young age ( $<5$ years; because of a greater long-term theoretical risk of malignancy) and active GO which can be exacerbated by RAI. Relative contraindications are age 5-10 years, inactive GO and large goiter that may need repeated treatment.

Side effects following RAI treatment in pediatric GD patients are extremely rare, although sometimes a mild tenderness over the thyroid may be observed in the first week after treatment. Observational studies in pediatric patients treated with RAI aiming at hypothyroidism reported no malignancies or fertility problems with a maximum follow-up of nearly four decades $(59,63,64,65)$.

Measures to be considered when preparing a pediatric patient for RAI are shown in Supplementary Table 2. ATD should be stopped 3-7 days prior to RAI administration. Patients with active GO should receive a course of steroids in accordance with EUGOGO guidelines (66). RAI should be administered according to local radiation protection law. After RAI, ATD treatment should be resumed 1-2 days after I-131 administration and continued for at least 3 months if a BR strategy is used, or titrated against thyroid hormone concentrations. TSH levels may not normalize for several months after RAI treatment. Patients and parents should be warned about a small risk of thyroid crisis post RAI treatment (67), although this is extremely rare in children (65). The first clinical and biochemical evaluation by the pediatric endocrinologist should be scheduled 4-6 weeks after RAI administration but can be brought forward depending on the pre-RAI treatment status. As the objective of RAI is complete thyroid ablation, lifelong LT4 replacement is usually necessary. If hyperthyroidism still persists at 12 months after RAI, a second course can be considered.

\section{Total thyroidectomy}

Total thyroidectomy aims to remove all overactive thyroid tissue. It is the preferred definitive treatment option for GD patients younger than 10 years, for patients with a (relative) contraindication for RAI treatment and for those with a large or nodular goiter. The advantage of total thyroidectomy is that it immediately cures hyperthyroidism by removing the source of excess thyroid hormone. Subsequent hypothyroidism necessitates lifelong LT4 treatment. Total thyroidectomy is preferred over subtotal thyroidectomy to reduce the risk of recurrent hyperthyroidism, with no reported difference in complications $(68,69)$.

Prior to surgery, patients need to be biochemically euthyroid to reduce the risk of anesthesia and thyroid storm. ATD treatment should be continued until the day of surgery. When euthyroidism cannot be achieved by ATD treatment alone, oral iodine (5-10 drops of Lugol's solution or 1-4 drops of saturated potassium iodide solution three times daily) can be administered for 1-2 weeks prior to surgery to normalize FT3. If surgery is not performed in a timely manner, then the patient may become thyrotoxic again. Pre-operative treatment with (c) 2022 European Thyroid Association Published by Bioscientifica Ltd.
This work is licensed under a Creative Commons Attribution-NonCommercial-NoDerivatives 4.0 International License.ifica.com at 04/26/2023 01:25:40PM 
a beta-blocker and glucocorticoid may be required (2). Patients should be vitamin D replete prior to surgery to reduce the risk of post-operative transient hypocalcemia and if in doubt can be treated with cholecalciferol for 3 days prior to surgery (60). After total thyroidectomy, LT4 treatment should be commenced in a weightappropriate dose.

Mortality post-thyroidectomy in pediatric GD patients is very low $(<0.1 \%)$. However, there are postoperative morbidities, including transient hypocalcemia (22.2\%) and recurrent laryngeal nerve (RLN) injury (5.4\%) (70). In addition, permanent hypoparathyroidism with hypocalcemia was reported in $2.5 \%$ and permanent RLN in $0.4 \%$ of pediatric GD patients (70). Post-operative infection, hemorrhage and keloid development are rare. Damage to the superior laryngeal nerve's external branch may occur after thyroidectomy and can have subtle effects on voice projection (71). The risk of post-operative morbidities is lower when thyroidectomy is performed by a high-volume thyroid surgeon.

\section{Radioiodine vs thyroidectomy}

The choice for RAI or total thyroidectomy is a contentious topic and will reflect local opinion and expertise. Each pediatric case warrants interdisciplinary consultation including a pediatric endocrinologist, thyroid surgeon and nuclear medicine physician specialized in thyroid disease; the choice of definitive treatment will involve shared decision making with the patient and the parents/legal guardians, focusing on the advantages and disadvantages of each option.

An absolute or relative contraindication for one modality vs another such as pregnancy or a markedly elevated risk of perioperative morbidity may direct treatment choice. Table 6 lists contraindications for and advantages and disadvantages of RAI and total thyroidectomy.

\section{Pediatric Graves' orbitopathy}

\section{Pathogenesis}

Pediatric GO is caused by autoreactivity to TSHR. Hyperthyroid children with GD and GO have higher TSHRAb levels than those with only hyperthyroid GD, and during ATD treatment, TSHRAb decreases less in children with GO $(46,72)$. The pathogenesis of GO is therefore the same in children as in adults (10).

\section{Epidemiology}

The frequency of GO in pediatric GD patients is $27-63 \%$ and is similar to adults $(47,72,73,74,75,76,77)$. In 19-69\%, family members also have thyroid dysfunction $(78,79,80)$. Female-to-male ratio is between 3.3 and 7.1 to 1 (75, 76, 78, $79,81)$. The time between diagnosing thyroid dysfunction and the onset of eye signs is usually less than 6 months. Like in adults, independent risk factors for $\mathrm{GO}$ are smoking $(\mathrm{OR}=7.098)$, TSHRAb $(\mathrm{OR}=6.358)$, stress $(\mathrm{OR}=6.030)$ and high FT4 at diagnosis (OR=5.963) (82).

\section{Signs and symptoms}

Eyelid retraction (median 72\%; range 23-91\%) and proptosis (median 53\%; range 4-92\%), best detected by comparison with photographs prior to the onset of GO, are the most frequent signs of GO in children with GD; soft tissue inflammation is less common (median 22\%; range $1-59 \%)$. In most retrospective and cross-sectional studies, impaired motility and dysthyroid optic neuropathy are rare or not reported, respectively. Accordingly, most patients have a mild course (7).

\section{Treatment and prognosis of orbitopathy in pediatric GD patients}

In most retrospective case series and cross-sectional studies, pediatric GD patients with GO are managed conservatively (70-100\%) because of mild underlying disease $(79,80)$. In patients with lagophthalmos artificial tears can be offered, but with good tear production and absence of meibomian gland dysfunction, eye drops and ointments are rarely needed. Rare cases of moderate-to-severe active GO cases can be treated with anti-inflammatory drugs (e.g. i.v. corticosteroids) (66). Selenium (Se) supplementation can prevent further deterioration in adults and can be offered to children when residing in an area of limited Se intake (83). A daily supplementation dosage of $1-2 \mu \mathrm{g} / \mathrm{kg}$ can be administered for 6 months (84).

Improvement of $\mathrm{GO}$ with normalization of thyroid function is frequently reported (7). Few patients need surgery (lid lengthening and rarely orbital decompression). Decompression surgery is best deferred until the facial skull has fully grown. Success rates are the same as in adults $(85,86)$. (c) 2022 European Thyroid Association Published by Bioscientifica Ltd.
This work is licensed under a Creative Commons Attribution-NonCommercial-NoDerivatives 4.0 International License.ifica.com at 04/26/2023 01:25:40PM 
Table 6 Specific indications and contraindications for, and pros and cons of, definitive treatment in pediatric Graves' disease: radioactive iodine vs surgery/total thyroidectomy.

\begin{tabular}{|c|c|c|}
\hline & Radioactive iodine & Total thyroidectomy \\
\hline General indications & $\begin{array}{l}\text { Relapse after ATD treatment, serious or persistent } \\
\text { side effects of ATDs, or poor compliance. }\end{array}$ & $\begin{array}{l}\text { Relapse after ATD treatment, serious or } \\
\text { persistent side effects of ATDs, or poor } \\
\text { compliance. }\end{array}$ \\
\hline Indications and & Absolute contraindication & Indications \\
\hline \multirow[t]{3}{*}{ contraindications } & $\begin{array}{l}\text { Pregnancy (pre-treatment pregnancy test is mandatory } \\
\text { from the moment of menarche) or breastfeeding. } \\
\text { Patients under } 5 \text { years of age. } \\
\text { Active GO. }\end{array}$ & $\begin{array}{l}\text { Obstructive symptoms from a large goiter. } \\
\text { When a euthyroid state is required quickly. } \\
\text { Patients under } 5 \text { years. }\end{array}$ \\
\hline & Relative contraindication & Contraindication \\
\hline & $\begin{array}{l}\text { Patients between } 5 \text { and } 10 \text { years of age. } \\
\text { Inactive GO. } \\
\text { Large goiter - second dose may be required. }\end{array}$ & $\begin{array}{l}\text { Essentially none, however, patients must } \\
\text { be euthyroid or have only mild thyroid } \\
\text { dysfunction at the time of surgery. }\end{array}$ \\
\hline \multicolumn{3}{|c|}{ 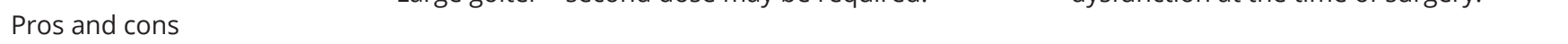 } \\
\hline Likelihood of hypothyroidism & $\begin{array}{l}\text { The success rate of achieving hypothyroidism } \\
\text { increases with a higher RAl activity dose. }\end{array}$ & $\begin{array}{l}100 \% \text { success rate of achieving } \\
\text { hypothyroidism when total } \\
\text { thyroidectomy is performed. }\end{array}$ \\
\hline Treatment process & $\begin{array}{l}\text { Usually administered orally (capsule) on an } \\
\text { outpatient basis. }\end{array}$ & Surgical procedure with admission. \\
\hline Time to hypothyroid state & Achieving hypothyroidism can take weeks or months. & Rapid achievement of hypothyroidism. \\
\hline Short-term logistics and risks & $\begin{array}{l}\text { Specific regulations need to be followed in the weeks } \\
\text { following treatment. }\end{array}$ & $\begin{array}{l}\text { General surgical risks and consequences, } \\
\text { like bleeding, infections, scar. }\end{array}$ \\
\hline Long-term risks & $\begin{array}{l}\text { General risks associated with ionizing radiation } \\
\text { including theoretical neoplasia risk. } \\
\text { Hypothetical risk of genetic damage to offspring: } \\
\text { mandatory advice not to become pregnant within } \\
6 \text { months after RAI. } \\
\text { Adolescent girls } \\
\text { Smaller chance of disappearance of TSHRAb } \\
\text { compared to total thyroidectomy, resulting in } \\
\text { greater risk of fetal or neonatal hyperthyroidism in } \\
\text { offspring (103). }\end{array}$ & $\begin{array}{l}\text { Risk of post-operative (transient or } \\
\text { permanent) morbidities: } \\
\text { hypoparathyroidism and/or recurrent } \\
\text { laryngeal nerve injury. }\end{array}$ \\
\hline Risk of thyroid cancer & $\begin{array}{l}\text { A histopathological diagnosis of thyroid (micro-) } \\
\text { carcinoma cannot be made (if present). }\end{array}$ & $\begin{array}{l}\text { Histopathological examination can be } \\
\text { performed and may show thyroid (micro) } \\
\text { carcinoma (if present). }\end{array}$ \\
\hline
\end{tabular}

ATD, antithyroid drug; GO, Graves' orbitopathy; RAI, radioactive iodine; TSHRAb, anti-TSH receptor antibodies.

\section{Treatment of thyroid disease in presence of orbitopathy}

Pediatric patients with GO are more likely to have a severe course of their GD and are less likely to go into remission following ATDs (77). Thyroid surgery is preferable to RAI treatment in active GO, and if there is a poor/absent response to GO treatment, then thyroidectomy may also reduce the risk of GO exacerbation $(66,87)$.

\section{Thyroid cancer risk in pediatric GD patients}

In $2-10 \%$ of adults undergoing thyroidectomy for GD, co-existing differentiated thyroid cancer (DTC) is found in surgical specimens (88). In $80 \%$ of cases, these are incidental microcarcinomas $(<10 \mathrm{~mm}$ in diameter), reflecting modern, detailed histological analysis. In some but not all studies, the rate of thyroid cancer detected is the same in adult GD patients as in those undergoing thyroidectomy for other benign thyroid diseases (89). However, several studies have found a slightly higher DTC rate in GD patients. Cappelli et al. found a cancer rate of $6.5 \%$ in GD patients undergoing thyroidectomy compared to $4.4 \%$ of those with solitary toxic nodules (90), and some studies found that tumors in adult GD patients may behave more aggressively $(91,92,93)$. A meta-analysis of 987 GD patients with DTC confirmed the higher prevalence of adverse prognostic features, but there was no difference in persistent disease or mortality (94). Several mechanisms have been postulated for these associations including the stimulation of thyrocyte proliferation by TSHRAbs and increased vascularity.
This work is licensed under a Creative Commons Attribution-NonCommercial-NoDerivatives 4.0

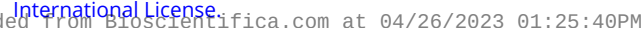


Despite the associations found in adults with Graves' disease, there is little information on this subject in pediatric GD patients. A retrospective analysis of young GD patients undergoing thyroidectomy at a single North American center showed that 7 of 32 (22\%) had differentiated thyroid cancer (95). In four patients, this was suspected from ultrasound and cytological workup pre-operatively, but in three, this was an incidental finding. The young patients with GD did not appear to have a worse prognosis than age-matched patients without GD (96).

Additional work is required, but in the interim, we recommend that all palpable thyroid nodules in children and adolescents with GD are subject to ultrasound evaluation. Patients with suspicious sonographic findings should either proceed to FNA cytological assessment or direct to total thyroidectomy. There is little role for 'diagnostic surgery' in this situation with total thyroidectomy the best treatment option.

\section{Prognosis}

It is important to discuss the various possible outcomes when managing GD. The first treatment goal is to restore euthyroidism. The most favorable long-term outcome is permanent functional and immunological remission without the need for medical treatment. Unfortunately, many children have a less favorable outcome: persistent thyroid autoimmunity and thyroid stimulation by TSHRAb necessitate lengthy medical, or definitive thyroid destructive therapy. Hence euthyroidism is achieved by long-term ATD or, after definitive treatment, by thyroid hormone replacement. Some children in remission may require thyroid hormone replacement at a later stage because of co-existing Hashimoto disease that evolves into hypothyroidism. Long-term follow-up studies in adults showed approximately one-quarter of patients in remission develops subclinical or overt Hashimoto hypothyroidism (97). Data on this in children are lacking. For young people/families opting for definitive treatment and thyroid hormone replacement, the aforementioned advantages and disadvantages of RAI and surgery need to be considered; the treating physician has an important role in counseling patients and parents.

Another important long-term outcome is quality of life (QoL). In a recent study in young people who were diagnosed with and treated for GD in childhood, QoL was found to be lower than in healthy controls, especially in the psychosocial domain. Although more research on this topic is needed, it emphasizes the need for additional support for young people with GD, both at school and from a psychological perspective (98).

\section{Conclusions}

This ETA guideline provides new recommendations for the management of pediatric GD including a longer phase of initial medical/ATD treatment, preference for DT instead of BR in most cases, complete thyroid gland ablation with personalized dose determination when using RAI and involvement of a pediatric endocrinologist in all cases.

\section{Supplementary materials}

This is linked to the online version of the paper at https://doi.org/10.1530/ ETJ-21-0073.

\section{Declaration of interest}

Simon Pearce received speaker fees from Merck, Sanofi, Berlin Chemie, Quidel and is member of the clinical advisory board of Apitope. The other authors have nothing to disclose.

\section{Funding}

The Department of Anja Eckstein received funding from Horizon Therapeutics plc to conduct clinical studies on the use of Teprotumamab in GO. No financial support was received writing this guideline.

\section{References}

1 Swiglo BA, Murad MH, Schunemann HJ, Kunz R, Vigersky RA, Guyatt GH \& Montori VM. A case for clarity, consistency, and helpfulness: state-of-the-art clinical practice guidelines in endocrinology using the grading of recommendations, assessment, development, and evaluation system. Journal of Clinical Endocrinology and Metabolism 2008 93 666-673. (https://doi.org/10.1210/jc.2007-1907)

2 De Leo S, Lee SY \& Braverman LE. Hyperthyroidism. Lancet 2016388 906-918. (https://doi.org/10.1016/S0140-6736(16)00278-6)

3 Hanley P, Lord K \& Bauer AJ. Thyroid disorders in children and adolescents: a review. JAMA Pediatrics 2016170 1008-1019. (https:// doi.org/10.1001/jamapediatrics.2016.0486)

4 Leger J \& Carel JC. Diagnosis and management of hyperthyroidism from prenatal life to adolescence. Best Practice and Research: Clinical Endocrinology and Metabolism 201832 373-386. (https://doi. org/10.1016/j.beem.2018.03.014)

5 García-Ascaso MT, Ares Segura S, Ros Pérez P, Piñeiro Pérez R \& Alfageme Zubillaga M. Thyroid volume assessment in 3-14 year-old Spanish children from an iodine-replete area. European Thyroid Journal 20198 196-201. (https://doi.org/10.1159/000499103)

6 Goldstein SM, Katowitz WR, Moshang T \& Katowitz JA. Pediatric thyroid-associated orbitopathy: the Children's Hospital of Philadelphia experience and literature review. Thyroid 200818 997-999. (https://doi.org/10.1089/thy.2008.0014) 
7 Szczapa-Jagustyn J, Gotz-Wieckowska A \& Kociecki J. An update on thyroid-associated ophthalmopathy in children and adolescents. Journal of Pediatric Endocrinology and Metabolism 201629 1115-1122. (https://doi.org/10.1515/jpem-2016-0122)

8 Kahaly GJ, Bartalena L, Hegedus L, Leenhardt L, Poppe K \& Pearce SH. European Thyroid Association guideline for the management of Graves' hyperthyroidism. European Thyroid Journal 20187 167-186. (https://doi.org/10.1159/000490384)

9 Smith TJ \& Hegedus L. Graves' disease. New England Journal of Medicine 2016375 1552-1565. (https://doi.org/10.1056/ NEJMra1510030)

10 Davies TF, Andersen S, Latif R, Nagayama Y, Barbesino G, Brito M, Eckstein AK, Stagnaro-Green A \& Kahaly GJ. Graves' disease. Nature Reviews: Disease Primers 20206 52. (https://doi.org/10.1038/s41572020-0184-y)

11 Krieger CC, Neumann S \& Gershengorn MC. TSH/IGF1 receptor crosstalk: mechanism and clinical implications. Pharmacology and Therapeutics 2020209 107502. (https://doi.org/10.1016/j. pharmthera.2020.107502)

12 Kumar S, Nadeem S, Stan MN, Coenen M \& Bahn RS. A stimulatory TSH receptor antibody enhances adipogenesis via phosphoinositide 3-kinase activation in orbital preadipocytes from patients with Graves' ophthalmopathy. Journal of Molecular Endocrinology 201146 155-163. (https://doi.org/10.1530/JME-11-0006)

13 Lee HJ, Li CW, Hammerstad SS, Stefan M \& Tomer Y. Immunogenetics of autoimmune thyroid diseases: a comprehensive review. Journal of Autoimmunity 201564 82-90. (https://doi.org/10.1016/j. jaut.2015.07.009)

14 Rydzewska M, Goralczyk A, Goscik J, Wawrusiewicz-Kurylonek N, Bossowska A, Kretowski A \& Bossowski A. Analysis of chosen polymorphisms rs2476601 a/G - PTPN22, rs1990760 C/T - IFIH1, rs179247 a/G - TSHR in pathogenesis of autoimmune thyroid diseases in children. Autoimmunity 201851 183-190. (https://doi.org/10.1080/ 08916934.2018.1486824)

15 Sawicka B, Borysewicz-Sanczyk H, Wawrusiewicz-Kurylonek N, Aversa T, Corica D, Goscik J, Krętowski A, Waśniewska M \& Bossowski A. Analysis of polymorphisms rs7093069-IL-2Ra, rs7138803-FAIM2, and rs1748033-PADI4 in the group of adolescents with autoimmune thyroid diseases. Frontiers in Endocrinology 202011 544658. (https://doi.org/10.3389/fendo.2020.544658)

16 Kus A, Radziszewski M, Glina A, Szymanski K, Jurecka-Lubieniecka B, Pawlak-Adamska E, Kula D, Wawrusiewicz-Kurylonek N, Kuś J, Miśkiewicz P, et al. Paediatric-onset and adult-onset Graves' disease share multiple genetic risk factors. Clinical Endocrinology 201990 320-327. (https://doi.org/10.1111/cen.13887)

17 Lane LC, Kus A, Bednarczuk T, Bossowski A, Daroszewski J, JureckaLubieniecka B, Cordell HJ, Pearce SHS, Cheetham T \& Mitchell AL. An intronic HCP5 variant is associated with age of onset and susceptibility to Graves disease in UK and Polish cohorts. Journal of Clinical Endocrinology and Metabolism 2020105 E3277-E3284. (https:// doi.org/10.1210/clinem/dgaa347)

18 Boelaert K, Newby PR, Simmonds MJ, Holder RL, Carr-Smith JD, Heward JM, Manji N, Allahabadia A, Armitage M, Chatterjee KV, et al. Prevalence and relative risk of other autoimmune diseases in subjects with autoimmune thyroid disease. American Journal of Medicine 2010 123 183.e1-183.e9. (https://doi.org/10.1016/j.amjmed.2009.06.030)

19 Sinha A, Abinun M, Gennery AR, Barge D, Slatter M \& Cheetham T. Graves' immune reconstitution inflammatory syndrome in childhood. Thyroid 201323 1010-1014. (https://doi.org/10.1089/ thy.2012.0618)

20 Abraham-Nordling M, Bystroom K, Torring O, Lantz M, Berg G, Calissendorff J, Nyström HF, Jansson S, Jörneskog G, Karlsson FA, et al. Incidence of hyperthyroidism in Sweden. European Journal of Endocrinology 2011165 899-905. (https://doi.org/10.1530/EJE-11-0548)

21 Simon M, Rigou A, Le Moal J, Zeghnoun A, Le Tertre A, De CrouyChanel P, Kaguelidou F \& Leger J. Epidemiology of childhood https://etj.bioscientifica.com https://doi.org/10.1530/ETJ-21-0073 (c) 2022 European Thyroid Association Published by Bioscientifica Ltd. hyperthyroidism in France: a nationwide population-based study. Journal of Clinical Endocrinology and Metabolism 2018103 2980-2987. (https://doi.org/10.1210/jc.2018-00273)

22 Williamson S \& Greene SA. Incidence of thyrotoxicosis in childhood: a national population based study in the UK and Ireland. Clinical Endocrinology 201072 358-363. (https://doi.org/10.1111/j.13652265.2009.03717.x)

23 Wong GWK \& Cheng PS. Increasing incidence of childhood Graves' disease in Hong Kong: a follow-up study. Clinical Endocrinology 2001 54 547-550. (https://doi.org/10.1046/j.1365-2265.2001.01252.x)

24 Rodanaki M, Lodefalk M, Forssell K, Arvidsson CG, Forssberg M \& Aman J. The incidence of childhood thyrotoxicosis is increasing in both girls and boys in Sweden. Hormone Research in Paediatrics 201991 195-202. (https://doi.org/10.1159/000500265)

25 Rivkees SA \& Mattison DR. Ending propylthiouracil-induced liver failure in children. New England Journal of Medicine 2009360 1574-1575. (https://doi.org/10.1056/NEJMc0809750)

26 Weetman AP, Mcgregor AM \& Hall R. Evidence for an effect of antithyroid drugs on the natural-history of Graves' disease. Clinical Endocrinology 198421 163-172. (https://doi. org/10.1111/j.1365-2265.1984.tb03456.x)

27 Manna D, Roy G \& Mugesh G. Antithyroid drugs and their analogues: synthesis, structure, and mechanism of action. Accounts of Chemical Research 201346 2706-2715. (https://doi.org/10.1021/ar4001229)

28 Shiroozu A, Okamura K, Ikenoue H, Sato K, Nakashima T, Yoshinari M, Fujishima M \& Yoshizumi T. Treatment of hyperthyroidism with a small single daily dose of methimazole. Journal of Clinical Endocrinology and Metabolism 198663 125-128. (https://doi. org/10.1210/jcem-63-1-125)

29 Roti E, Gardini E, Minelli R, Salvi M, Robuschi G \& Braverman LE Methimazole and serum thyroid-hormone concentrations in hyperthyroid patients - effects of single and multiple daily doses. Annals of Internal Medicine 1989111 181-182. (https://doi. org/10.7326/0003-4819-111-2-181)

30 Sriussadaporn S, Pumchumpol W, Lertwattanarak R \& Kunavisarut T. Efficacy of once daily versus divided daily administration of low daily dosage ( $15 \mathrm{mg}$ /day) of methimazole in the induction of euthyroidism in Graves' hyperthyroidism: a randomized controlled study. International Journal of Endocrinology 20172017 2619695. (https://doi. org/10.1155/2017/2619695)

31 Wood CL, Cole M, Donaldson M, Dunger DB, Wood R, Morrison N, Matthews JNS, Pearce SHS \& Cheetham TD. Randomised trial of block and replace vs dose titration thionamide in young people with thyrotoxicosis. European Journal of Endocrinology 2020183 637-645. (https://doi.org/10.1530/EJE-20-0617)

32 Raza J, Hindmarsh PC \& Brook CGD. Thyrotoxicosis in children: thirty years' experience. Acta Paediatrica 199988 937-941. (https://doi. org/10.1080/08035259950168405)

33 Vaidya B, Wright A, Shuttleworth J, Donohoe M, Warren R, Brooke A, Gericke CA \& Ukoumunne OC. Block and replace regime versus titration regime of antithyroid drugs for the treatment of Graves' disease: a retrospective observational study. Clinical Endocrinology 2014 81 610-613. (https://doi.org/10.1111/cen.12478)

34 Vigone MC, Peroni E, Di Frenna M, Mora S, Barera G \& Weber G. 'Block-and-replace' treatment in Graves' disease: experience in a cohort of pediatric patients. Journal of Endocrinological Investigation 202043 595-600. (https://doi.org/10.1007/s40618-019-01144-0)

35 Tagami T, Yambe Y, Tanaka T, Tanaka T, Ogo A, Yoshizumi H, Kaise K, Higashi K, Tanabe M, Shimazu S, et al. Short-term effects of betaadrenergic antagonists and methimazole in new-onset thyrotoxicosis caused by Graves' disease. Internal Medicine $2012512285-2290$. (https://doi.org/10.2169/internalmedicine.51.7302)

36 Aggarwal N, Tee SA, Saqib W, Fretwell T, Summerfield GP \& Razvi S. Treatment of hyperthyroidism with antithyroid drugs corrects mild neutropenia in Graves' disease. Clinical Endocrinology 201685 949-953. (https://doi.org/10.1111/cen.13133) 
37 Yan LD, Thomas D, Schwartz M, Reich J \& Steenkamp D. Rescue of Graves thyrotoxicosis-induced cholestatic liver disease without antithyroid drugs: a case report. Journal of the Endocrine Society $2017 \mathbf{1}$ 231-236. (https://doi.org/10.1210/js.2016-1065)

38 van Veenendaal NR \& Rivkees SA. Treatment of pediatric Graves' disease is associated with excessive weight gain. Journal of Clinical Endocrinology and Metabolism 201196 3257-3263. (https://doi. org/10.1210/jc.2011-1601)

39 Arab DM, Malatjalian DA \& Rittmaster RS. Severe cholestatic jaundice in uncomplicated hyperthyroidism treated with methimazole. Journal of Clinical Endocrinology and Metabolism 199580 1083-1085. (https:// doi.org/10.1210/jcem.80.4.7714072)

40 van Lieshout JM, Mooij CF, van Trotsenburg ASP \& ZwavelingSoonawala N. Methimazole-induced remission rates in pediatric Graves' disease: a systematic review. European Journal of Endocrinology 2021185 219-229. (https://doi.org/10.1530/EJE-21-0077)

41 Lazar L, Kalter-Leibovici O, Pertzelan A, Weintrob N, Josefsberg Z \& Phillip M. Thyrotoxicosis in prepubertal children compared with pubertal and postpubertal patients. Journal of Clinical Endocrinology and Metabolism 200085 3678-3682. (https://doi.org/10.1210/ jcem.85.10.6922)

42 Ohye H, Minagawa A, Noh JY, Mukasa K, Kunii Y, Watanabe N, Matsumoto M, Suzuki M, Yoshihara A, Ito K, et al. Antithyroid drug treatment for Graves' disease in children: a long-term retrospective study at a single institution. Thyroid 201424 200-207. (https://doi. org/10.1089/thy.2012.0612)

43 Pearce SHS. Spontaneous reporting of adverse reactions to carbimazole and propylthiouracil in the UK. Clinical Endocrinology 200461 589-594. (https://doi.org/10.1111/j.1365-2265.2004.02135.x)

44 Rivkees SA, Stephenson K \& Dinauer C. Adverse events associated with methimazole therapy of Graves' disease in children. International Journal of Pediatric Endocrinology 20102010 176970. (https://doi. org/10.1155/2010/176970)

45 Harvengt J, Boizeau P, Chevenne D, Zenaty D, Paulsen A, Simon D, Guilmin Crepon S, Alberti C, Carel JC \& Léger J. Triiodothyroninepredominant Graves' disease in childhood: detection and therapeutic implications. European Journal of Endocrinology 2015172 715-723. (https://doi.org/10.1530/EJE-14-0959)

46 Diana T, Brown RS, Bossowski A, Segni M, Niedziela M, Konig J, Bossowska A, Ziora K, Hale A, Smith J, et al. Clinical relevance of thyroid-stimulating autoantibodies in pediatric Graves' disease - a multicenter study. Journal of Clinical Endocrinology and Metabolism 201499 1648-1655. (https://doi.org/10.1210/jc.2013-4026)

47 Kaguelidou F, Alberti C, Castanet M, Guitteny MA, Czernichow P, Leger J \& French Childhood Graves' Disease Study Group. Predictors of autoimmune hyperthyroidism relapse in children after discontinuation of antithyroid drug treatment. Journal of Clinical Endocrinology and Metabolism 200893 3817-3826. (https://doi. org/10.1210/jc.2008-0842)

48 Leger J, Gelwane G, Kaguelidou F, Benmerad M, Alberti C \& French Childhood Graves' Disease Study Group. Positive impact of longterm antithyroid drug treatment on the outcome of children with Graves' disease: national long-term cohort study. Journal of Clinical Endocrinology and Metabolism 201297 110-119. (https://doi. org/10.1210/jc.2011-1944)

49 Azizi F, Takyar M, Madreseh E \& Amouzegar A. Long-term methimazole therapy in juvenile Graves' disease: a randomized trial. Pediatrics 2019 143 e20183034. (https://doi.org/10.1542/peds.2018-3034)

50 Gastaldi R, Poggi E, Mussa A, Weber G, Vigone MC, Salerno M, Delvecchio M, Peroni E, Pistorio A \& Corrias A. Graves disease in children: thyroid-stimulating hormone receptor antibodies as remission markers. Journal of Pediatrics 2014164 1189.e1-1194.e1. (https://doi.org/10.1016/j.jpeds.2013.12.047)

51 Wood LC \& Ingbar SH. Hypothyroidism as a late sequela in patients with Graves' disease treated with anti-thyroid agents. Journal of
Clinical Investigation 197964 1429-1436. (https://doi.org/10.1172/ JCI109601)

52 El Fassi D, Nielsen CH, Hasselbalch HC \& Hegedus L. Treatmentresistant severe, active Graves' ophthalmopathy successfully treated with B lymphocyte depletion. Thyroid 200616 709-710. (https://doi. org/10.1089/thy.2006.16.709)

53 Salvi M, Vannucchi G, Campi I, Rossi S, Bonara P, Sbrozzi F, Guastella C, Avignone S, Pirola G, Ratiglia R, et al. Efficacy of rituximab treatment for thyroid-associated ophthalmopathy as a result of intraorbital B-cell depletion in one patient unresponsive to steroid immunosuppression. European Journal of Endocrinology 2006 154 511-517. (https://doi.org/10.1530/eje.1.02119)

54 El Fassi D, Nielsen CH, Bonnema SJ, Hasselbalch HC \& Hegedus L. B lymphocyte depletion with the monoclonal antibody rituximab in Graves' disease: a controlled pilot study. Journal of Clinical Endocrinology and Metabolism 200792 1769-1772. (https://doi. org/10.1210/jc.2006-2388)

55 Salvi M, Vannucchi G, Campi I, Curro N, Dazzi D, Simonetta S, Bonara P, Rossi S, Sina C, Guastella C, et al. Treatment of Graves' disease and associated ophthalmopathy with the anti-CD20 monoclonal antibody rituximab: an open study. European Journal of Endocrinology 2007156 33-40. (https://doi.org/10.1530/eje.1.02325)

56 Heemstra KA, Toes RE, Sepers J, Pereira AM, Corssmit EP, Huizinga TWJ, Romijn JA \& Smit JW. Rituximab in relapsing Graves' disease, a phase II study. European Journal of Endocrinology $2008 \mathbf{1 5 9}$ 609-615. (https://doi.org/10.1530/EJE-08-0084)

57 Cole M, Hynes AM, Howel D, Hall L, Abinun M, Allahabadia A, Barrett T, Boelaert K, Drake AJ, Dimitri P, et al. Adjuvant rituximab, a potential treatment for the young patient with Graves' hyperthyroidism (RiGD): study protocol for a single-arm, single-stage, phase II trial. BMJ Open 20199 e024705. (https://doi.org/10.1136/ bmjopen-2018-024705)

58 Furmaniak J, Sanders J, Sanders P, Miller-Gallacher J, Ryder MM \& Smith BR. Practical applications of studies on the TSH receptor and TSH receptor autoantibodies. Endocrine 202068 261-264. (https://doi. org/10.1007/s12020-019-02180-9)

59 Rivkees SA \& Dinauer C. An optimal treatment for pediatric Graves' disease is radioiodine. Journal of Clinical Endocrinology and Metabolism 200792 797-800. (https://doi.org/10.1210/jc.2006-1239)

60 Rivkees SA. Pediatric Graves' disease: management in the postpropylthiouracil era. International Journal of Pediatric Endocrinology 20142014 10. (https://doi.org/10.1186/1687-9856-2014-10)

61 Stokkel MPM, Junak DH, Lassmann M, Dietlein M \& Luster M. EANM procedure guidelines for therapy of benign thyroid disease. European Journal of Nuclear Medicine Molecular Imaging 201037 2218-2228. (https://doi.org/10.1007/s00259-010-1536-8)

62 Silberstein EB, Alavi A, Balon HR, Clarke SEM, Divgi C, Gelfand MJ, Goldsmith SJ, Jadvar H, Marcus CS, Martin WH, et al. The SNMMI practice guideline for therapy of thyroid disease with I-131 3.0. Journal of Nuclear Medicine 201253 1633-1651. (https://doi.org/10.2967/ jnumed.112.105148)

63 Read CH, Tansey MJ \& Menda Y. A 36-year retrospective analysis of the efficacy and safety of radioactive iodine in treating young Graves' patients. Journal of Clinical Endocrinology and Metabolism 200489 4229-4233. (https://doi.org/10.1210/jc.2003-031223)

64 Mizokami T, Hamada K, Maruta T, Higashi K \& Tajiri J. Long-term outcomes of radioiodine therapy for juvenile Graves disease with emphasis on subsequently detected thyroid nodules: a single institution experience from Japan. Endocrine Practice 202026 729-737. (https://doi.org/10.4158/EP-2019-0468)

65 Lutterman SL, Zwaveling-Soonawala N, Verberne HJ, Verburg FA, van Trotsenburg ASP \& Mooij CF. The efficacy and short- and long-term side effects of radioactive iodine treatment in pediatric Graves' disease: a systematic review. European Thyroid Journal $202110353-363$. (https://doi.org/10.1159/000517174) https://etj.bioscientifica.com https://doi.org/10.1530/ETJ-21-0073 (c) 2022 European Thyroid Association Published by Bioscientifica Ltd.
This work is licensed under a Creative Commons Attribution-NonCommercial-NoDerivatives 4.0 International License . $\mathrm{fica}$ com at $04 / 26 / 2023$ 01:25:40PM 
66 Bartalena L, Baldeschi L, Boboridis K, Eckstein A, Kahaly GJ, Marcocci C, Perros P, Salvi M, Wiersinga WM \& European Group on Graves' Orbitopathy (EUGOGO). The 2016 European Thyroid Association/European Group on Graves' Orbitopathy Guidelines for the management of Graves' orbitopathy. European Thyroid Journal 2016 5 9-26. (https://doi.org/10.1159/000443828)

67 Rohrs 3rd HJ, Silverstein JH, Weinstein DA, Amdur RJ \& Haller MJ. Thyroid storm following radioactive iodine (RAI) therapy for pediatric Grave's disease. American Journal of Case Reports 201415 212-215. (https://doi.org/10.12659/AJCR.890366)

68 Palit TK, Miller CC \& Miltenburg DM. The efficacy of thyroidectomy for Graves' disease: a meta-analysis. Journal of Surgical Research 200090 161-165. (https://doi.org/10.1006/jsre.2000.5875)

69 Annerbo M, Stalberg P \& Hellman P. Management of Grave's disease is improved by total thyroidectomy. World Journal of Surgery 201236 1943-1946. (https://doi.org/10.1007/s00268-012-1617-x)

70 Zaat AS, Derikx JPM, Zwaveling-Soonawala N, van Trotsenburg ASP \& Mooij CF. Thyroidectomy in pediatric patients with Graves' disease: a systematic review of postoperative morbidity. European Thyroid Journal 2021 10 39-51. (https://doi.org/10.1159/000511345)

71 Potenza AS, Araujo VJF \& Cernea CR. Injury of the external branch of the superior laryngeal nerve in thyroid surgery. Gland Surgery 20176 552-562. (https://doi.org/10.21037/gs.2017.06.15)

72 Acuna OM, Athannassaki I \& Paysse EA. Association between thyroid-stimulating immunoglobulin levels and ocular findings in pediatric patients with Graves disease. Transactions of the American Ophthalmological Society 2007105 146-150; discussion 50-51.

73 Young LA. Dysthyroid ophthalmopathy in children. Journal of Pediatric Ophthalmology and Strabismus 197916 105-107. (https://doi. org/10.3928/0191-3913-19790301-05)

74 Uretsky SH, Kennerdell JS \& Gutai JP. Graves' ophthalmopathy in childhood and adolescence. Archives of Ophthalmology 198098 1963-1964. (https://doi.org/10.1001/archo pht.1980.01020040815002)

75 Gruters A. Ocular manifestations in children and adolescents with thyrotoxicosis. Experimental and Clinical Endocrinology and Diabetes 1999107 (Supplement 5) S172-S174. (https://doi. org/10.1055/s-0029-1212178)

76 Holt H, Hunter DG, Smith J \& Dagi LR. Pediatric Graves' ophthalmopathy: the pre- and postpubertal experience. Journal of AAPOS 200812 357-360. (https://doi.org/10.1016/j. jaapos.2007.12.011)

77 Jankauskiene J \& Jarusaitiene D. The influence of juvenile Graves ophthalmopathy on Graves' disease course. Journal of Ophthalmology 20172017 4853905. (https://doi.org/10.1155/2017/4853905)

78 Chan W, Wong GW, Fan DS, Cheng AC, Lam DS \& Ng JS. Ophthalmopathy in childhood Graves' disease. British Journal of Ophthalmology 200286 740-742. (https://doi.org/10.1136/ bjo.86.7.740)

79 Durairaj VD, Bartley GB \& Garrity JA. Clinical features and treatment of Graves ophthalmopathy in pediatric patients. Ophthalmic Plastic and Reconstructive Surgery 200622 7-12. (https://doi.org/10.1097/01. iop.0000195006.08929.46)

80 Lim NC, Amrith S \& Sundar G. Pediatric thyroid eye disease - the Singapore experience. Orbit 201433 96-103. (https://doi.org/10.3109/ 01676830.2013.851258)

81 Jevalikar G, Solis J \& Zacharin M. Long-term outcomes of pediatric Graves' disease. Journal of Pediatric Endocrinology and Metabolism 2014 27 1131-1136. (https://doi.org/10.1515/ipem-2013-0342)

82 Jarusaitiene D, Verkauskiene R, Jasinskas V \& Jankauskiene J. Predictive factors of development of Graves' ophthalmopathy for patients with juvenile Graves' disease. International Journal of Endocrinology 20162016 8129497. (https://doi org/10.1155/2016/8129497)

83 Marcocci C, Kahaly GJ, Krassas GE, Bartalena L, Prummel M, Stahl M, Altea MA, Nardi M, Pitz S, Boboridis K, et al. Selenium and the course of mild Graves' orbitopathy. New England Journal of Medicine 2011364 1920-1931. (https://doi.org/10.1056/NEJMoa1012985)

84 Calomme MR, Vanderpas JB, Francois B, VanCaillieBertrand M, Herchuelz A, Vanovervelt N, Van Hoorebeke C \& Vanden Berghe DA. Thyroid function parameters during a selenium repletion depletion study in phenylketonuric subjects. Experientia 199551 1208-1215. (https://doi.org/10.1007/BF01944738)

85 Wu CY, Elner VM \& Kahana A. Severe pediatric thyroid eye disease: surgical case series. Ophthalmic Plastic and Reconstructive Surgery 201733 (3S Supplement 1) S186-S188. (https://doi.org/10.1097/ IOP.0000000000000585)

86 Chua MR, Tomlinson LA, Binenbaum G \& Katowitz WR. Pediatric thyroid eye disease: clinical characteristics and orbital decompression outcomes. Ophthalmic Plastic and Reconstructive Surgery 201834 (4S Supplement 1) S52-S55. (https://doi.org/10.1097/ IOP.0000000000001137)

87 Ma C, Kuang A, Xie J \& Liu G. Radioiodine treatment for pediatric Graves' disease. Cochrane Database of Systematic Reviews 20083 CD006294. (https://doi.org/10.1002/14651858.CD006294.pub2)

88 Pazaitou-Panayiotou K, Michalakis K \& Paschke R. Thyroid cancer in patients with hyperthyroidism. Hormone and Metabolic Research 2012 44 255-262. (https://doi.org/10.1055/s-0031-1299741)

89 Jia QY, Li XD, Liu Y, Li L, Kwong JSW, Ren KY, Jiang Y, Sun X, Tian H $\&$ Li S. Incidental thyroid carcinoma in surgery-treated hyperthyroid patients with Graves' disease: a systematic review and meta-analysis of cohort studies. Cancer Management and Research 201810 1201-1207. (https://doi.org/10.2147/CMAR.S164210)

90 Cappelli C, Braga M, Martino ED, Castellano M, Gandossi E, Agosti B Cumetti D, Pirola I, Mattanza C, Cherubini L, et al. Outcome of patients surgically treated for various forms of hyperthyroidism with differentiated thyroid cancer: experience at an endocrine center in Italy. Surgery Today 200636 125-130. (https://doi.org/10.1007/s00595005-3115-3)

91 Belfiore A, Garofalo MR, Giuffrida D, Runello F, Filetti S, Fiumara A, Ippolito $\mathrm{O} \&$ Vigneri R. Increased aggressiveness of thyroid-cancer in patients with Graves' disease. Journal of Clinical Endocrinology and Metabolism 199070 830-835. (https://doi.org/10.1210/jcem-70-4-830)

92 Medas F, Erdas E, Canu GL, Longheu A, Pisano G, Tuveri M \& Calò PG. Does hyperthyroidism worsen prognosis of thyroid carcinoma? A retrospective analysis on 2820 consecutive thyroidectomies. Journal of Otolaryngology: Head and Neck Surgery 201847 6. (https://doi. org/10.1186/s40463-018-0254-2)

93 Premoli P, Tanda ML, Piantanida E, Veronesi G, Gallo D, Masiello E, Rosetti S, Cusini C, Boi F, Bulla J, et al. Features and outcome of differentiated thyroid carcinoma associated with Graves' disease: results of a large, retrospective, multicenter study. Journal of Endocrinological Investigation 202043 109-116. (https://doi. org/10.1007/s40618-019-01088-5)

94 Mekraksakit P, Rattanawong P, Karnchanasorn R, Kanitsoraphan C, Leelaviwat N, Poonsombudlert K, Kewcharoen J, Dejhansathit S \& Samoa R. Prognosis of differentiated thyroid carcinoma in patients with Graves disease: a systematic review and meta-analysis. Endocrine Practice 201925 1323-1337. (https://doi.org/10.4158/EP-2019-0201)

95 Kovatch KJ, Bauer AJ, Isaacoff EJ, Prickett KK, Adzick NS, Kazahaya K, Sullivan LM \& Mostoufi-Moab S. Pediatric thyroid carcinoma in patients with Graves' disease: the role of ultrasound in selecting patients for definitive therapy. Hormone Research in Paediatrics 201583 408-413. (https://doi.org/10.1159/000381185)

96 MacFarland SP, Bauer AJ, Adzick NS, Surrey LF, Noyes J, Kazahaya K \& Mostoufi-Moab S. Disease burden and outcome in children and young adults with concurrent Graves disease and differentiated thyroid carcinoma. Journal of Clinical Endocrinology and Metabolism 2018103 2918-2925. (https://doi.org/10.1210/jc.2018-00026)

97 Wiersinga WM. Graves' disease: can it be cured? Endocrinology and Metabolism 201934 29-38. (https://doi.org/10.3803/ EnM.2019.34.1.29) 
98 Lane LC, Rankin J \& Cheetham T. A survey of the young person's experience of Graves' disease and its management. Clinical Endocrinology 202194 330-340. (https://doi.org/10.1111/cen.14359)

99 Shulman DI, Muhar I, Jorgensen EV, Diamond FB, Bercu BB \& Root AW. Autoimmune hyperthyroidism in prepubertal children and adolescents: comparison of clinical and biochemical features at diagnosis and responses to medical therapy. Thyroid 1997 755-760. (https://doi.org/10.1089/thy.1997.7.755)

100 Allahabadia A, Daykin J, Holder RL, Sheppard MC, Gough SCL \& Franklyn JA. Age and gender predict the outcome of treatment for Graves' hyperthyroidism. Journal of Clinical Endocrinology and Metabolism 200085 1038-1042. (https://doi.org/10.1210/ jcem.85.3.6430)
101 Glaser NS \& Styne DM. Predictors of early remission of hyperthyroidism in children. Journal of Clinical Endocrinology and Metabolism 199782 1719-1726. (https://doi.org/10.1210/ jcem.82.6.3986)

102 Leger J \& Carel JC. MANAGEMENT OF ENDOCRINE DISEASE: Arguments for the prolonged use of antithyroid drugs in children with Graves' disease. European Journal of Endocrinology 2017177 R59-R67. (https://doi.org/10.1530/EJE-16-0938)

103 van Trotsenburg ASP. Management of neonates born to mothers with thyroid dysfunction, and points for attention during pregnancy. Best Practice and Research: Clinical Endocrinology and Metabolism 202034 101437. (https://doi.org/10.1016/j. beem.2020.101437)

Received in final form 27 October 2021

Accepted 4 November 2021

Accepted Manuscript published online 5 November 2021 (c) 2022 European Thyroid Association Published by Bioscientifica Ltd.
This work is licensed under a Creative Commons Attribution-NonCommercial-NoDerivatives 4.0

International License.ifica.com at 04/26/2023 01:25:40PM 